À l'intersection des discours de spécialité :

hétérogénéité et unité

\title{
A linguistic and discursive view on climate change discourse
}

Kjersti Fløttum

\section{(2) OpenEdition}

\section{Journals}

Electronic version

URL: http://journals.openedition.org/asp/1793

DOI: 10.4000/asp. 1793

ISBN: 978-2-8218-0414-2

ISSN: 2108-6354

\section{Publisher}

Groupe d'étude et de recherche en anglais de spécialité

\section{Printed version}

Date of publication: 30 November 2010

Number of pages: 19-37

ISSN: 1246-8185

\section{Electronic reference}

Kjersti Fløttum, «A linguistic and discursive view on climate change discourse », ASp [Online], 58

2010, Online since 30 November 2013, connection on 02 November 2020. URL : http://

journals.openedition.org/asp/1793; DOI : https://doi.org/10.4000/asp.1793

This text was automatically generated on 2 November 2020.

Tous droits réservés 


\title{
A linguistic and discursive view on climate change discourse
}

\author{
Kjersti Fløttum
}

\section{Introduction}

1 As a general backdrop for my presentation, I would like to point to the following question: To what extent can we - i.e., a 'we' referring to the whole of mankind - ever hope to agree on what to do about the climate challenges, understood as a global issue? The same question is raised by Elizabeth L. Malone in her book Debating climate change (Malone 2009: 1). This is a preoccupation that many of us share, both experts and ordinary citizens of the world, and one of the reasons is that climate change is a global challenge in which "many kinds of knowledge may be contested" (ibid.). And it may seem quite hopeless to reach such an agreement which could lead to fruitful and responsible actions for us all. However, this will not be my message here. I would like to take a more constructive position, based on a scientific and somewhat programmatic backdrop: If there are going to be any agreements at all, be they multi- or bilateral, global, regional or national, and if there are going to be sound and relevant actions, we at least need to know what is actually said and discussed and by whom, in the climate change debate. There is in fact a substantial need for linguistics and language use analyses in this multidisciplinary field of what could be called the climate change narrative. The issue at stake is the transfer of knowledge from science to politics, a transfer realised through language.

2 Thus, we are at the intersection of specialised discourses. But we need more research in order to answer the questions of how various fields and discourses influence each other. Regarding the climate change narratives, they may come in many different varieties, from purely scientific reports and papers at one end, to action- and policyoriented rhetorical pieces at the other end. There is often a textual outcome which we could call "a co-production of knowledge and politics" (St. Clair 2006). 
3 I will now return to my claim for linguistic analyses of climate change discourse, by looking at a passage taken from an Internet discussion, the Environmental Law and Climate Change Law Blog, accessed on $5^{\text {th }}$ February 2010:

(1) The overwhelming scientific evidence, thought, scholarship and work show that climate change is a reality. While there is a shade less consensus as to whether that change is anthropogenic, there is no doubt that decreasing the human emission of known greenhouse gases would alleviate the effects of the climate change wherever it might have come from. Thus, at least in my mind, in order for the sceptics to successfully stave off regulation of greenhouse gases, they would have to show that climate change in general does not exist - not just that climate change is not human-made.

4 As the climate change debate is rapidly evolving, we hear a multitude of voices, as in this example. Different actors are getting involved in addressing the challenges, setting priorities for new knowledge, and framing key questions and actions. Whose voices are these? To what extent do they have shared understandings of the challenges? And how are they "translating" each other's knowledge?

5 In order to answer these questions, it is necessary to study how climate knowledge, which has its origin in "objective" scientific discourse, is transmitted to public and political argumentative or action-oriented discourse. How do actors at different levels and in different contexts construct their climate politics discursively? The interdisciplinary research project to which the present contribution is related aims to unpack this polyphonic discourse.

6 Let me take another example from my part of the world, Bergen in Norway, which usually has wet and relatively mild winters. This year we have had a heated public debate because of an unusually cold winter with large amounts of snow. People are asking what we should believe in - global warming or global freezing? Experts have had to come forth and explain that climate is something very different from weather. While we can both see, feel and measure the weather every day, it takes decades and centuries to observe and measure the climate. This also demonstrates the complexity and uniqueness of the climate issue. If we are to understand that we still have global warming while experiencing record levels of snow, we must also understand the difference between climate and weather. These words are just simple examples of how important the language use is in this context.

7 Let us look at an example taken from a climate discourse text that I will come back to for a more thorough analysis - the IPCC 2007 "Summary for policymakers" edited by the Intergovernmental Panel on Climate Change (IPCC):

(2) Of the more than 29,000 observational data series, from 75 studies, that show significant change in many physical and biological systems, more than $89 \%$ are consistent with the direction of change expected as a response to warming (Figure SPM.2). However, ${ }^{1}$ there is a notable lack of geographic balance in data and literature on observed changes, with marked scarcity in developing countries. (IPCC 2007: 2-3)

8 This example presents some of the overwhelming scientific bases on which climate scientists rely. We also see that there is a discussion between different voices here, signalled by the connective however. In fact, in the clause introduced by however there are both an implicit push towards more research and action, as well as a hint to issues related to development. It is obvious that a large number of climate narratives are situated between science and politics. We need linguistic and discourse studies to 
identify and explain these intersections between different, and sometimes mixed, specialised discourses.

Recent linguistic research clearly shows that the traditional conception of scientific discourse as objective or neutral is outdated (Fløttum, Dahl \& Kinn 2006; Hyland 1998, 2000; Prelli 1989; Rinck, Boch \& Grossmann 2007; Swales 1990). Scientific reporting is becoming continuously more rhetorical and thus more similar to political discourse. However, there are of course differences between scientific and political discourse. One reason is that a central purpose of scientific discourse is (or should be) to describe and explain facts and findings, while the purpose of political discourse is to convince or to persuade someone to take action (for some recent research with different perspectives on political discourse, see Charaudeau 2005; Fløttum 2010; Fløttum \& Gjerstad forthcoming; Fløttum \& Stenvoll 2009; Gjerstad 2007, forthcoming; Mayaffre 2007; Poudat \& Mayaffre 2009; Rouveyrol 2009; Weiss 2002; Wodak \& Chilton 2005; Wodak \& Weiss 2004).

In this paper I will present parts of an analysis undertaken on the document just mentioned above, the IPCC summary, which takes climate research findings as a point of departure but with additional emphasis on the need of adaptation, mitigation and political action.

11 The structure of my paper will be as follows: After this introduction (section 1), my presentation will contain elements from different dimensions related to language use, contextual in Section 2 (the situation in which the document is produced) and linguistic in Section 3, both on a macro- (3.1) and a micro- (3.2) level. The main attention will be given to Section 3.2, where the following features will be studied: personal pronouns, knowledge claims, epistemic modifiers, and markers of concession and refusal in polyphonic use. These features are all central - some primarily in science, some primarily in politics. They are all studied in the scope of polyphony, using questions such as "what is expressed?", "by whom?", "whose responsibility is implicated?" as starting-points.

In section 4, I will very briefly mention an analysis undertaken on a "Position statement on climate change and related issues" written by the South-African Applied Center for Climate and Earth Systems Science (ACCESS). The purpose of this comparison is, inter alia, to start a discussion, in Section 5 , on what could be called climate narratives, in a genre perspective.

\section{Contextual description of IPPC's “Summary for Policymakers"}

13 In multidisciplinary studies where linguistics is involved as well as in discourse analysis, the relationship text-context has to be considered (for a selection of different approaches, see Adam 1999; Chilton \& Schäffner 2002; Mellet \& Longrée 2009; Rastier 1998; Rowley-Jolivet \& Carter-Thomas 2008; Wodak \& Chilton 2005; Van Dijk 1997). However, the question of how much and what kind of context one should take into consideration when leaving the pure linguistic level and entering the interpretation phase, is subject to many and different discussions. My intention is not to go into this matter here, but I would like to present briefly what might be called the institutional context of the IPCC summary. It is based on a huge number of scientific papers, 
published by scientists and addressed to policymakers. This makes it an obvious example of knowledge asymmetry, a dimension I will not go into here (Fløttum \& Dahl forthcoming), but which of course is central for communication issues.

The IPCC panel presents itself as follows. It should:

- provide the world with a clear scientific view on the current state of climate change and its potential environmental and socio-economic consequences;

- ensure an objective and complete assessment of current information. Differing viewpoints existing within the scientific community are reflected in the IPCC reports.

[...] The work of the organisation is therefore policy-relevant and yet policy-neutral, never policy-prescriptive.

Questions of interest would be: Is the scientific view sufficiently "clear", for the entire world? How are the "[d]iffering viewpoints" reflected? To what extent is it "policyrelevant and yet policy-neutral"? My analysis should give elements for answering these questions.

\section{Macro- and micro-linguistic/discursive analysis}

\subsection{A macro perspective on the IPCC Summary}

In order to understand not only bits and pieces of this document, it seems relevant to take a quick look at the overall macro-structure. This may also help to situate the text in a genre perspective. I will not undertake a traditional detailed thematic analysis here. My main perspective and what I consider as particularly important, is how things are said, what voices are present, and how the responsibilities of the points of view included are distributed. This is all related to the issue of transfer from science to politics.

I will first take a look at the macro-structure of the summary. In addition to a large number of figures and tables, not considered here, it contains five sections:

1. Observed changes in climate and their effects

2. Causes of change

3. Projected climate change and its impacts

4. Adaptation and mitigation options

5. The long-term perspective

These are thematic section titles, which may seem natural since the text is addressed to policymakers. However, if we look more closely at the sections, they resemble to a large extent the IMRAD structure (Introduction, Material/Method, Results, And Discussion; see Swales 1990), but without the Introduction. The order of the sections is also slightly different.

This similarity is interesting but not surprising. IMRAD is the typical genre structure of a published research paper, and we know that the scientists behind the summary are very much used to this strict structure, clearly dominating in the disciplines of natural sciences.

It is reasonable to think that many of these scientists are not used to presentations for political action. Also, even if the subtitles are thematic, we see that there are clear 
traces of scientific methodology and vocabulary, such as observed, causes, and projected. I can here only develop this genre aspect very briefly.

First, section 1, "Observed changes in climate and their effects", is very similar in form to the Results section in IMRAD. Section 2, "Causes of change", is a mix, with some background information and results, but to a large extent presenting methods and facts about the material, thus corresponding to the Method/Material section of IMRAD. Section 3 then, "Projected climate change and its impacts, contains clear components of what is usually found in the Discussion section". This is marked by more modal expressions such as would, could, may and especially by argumentative and polyphonic connectives such as even if, but, however, nevertheless. As regards section 4, "Adaptation and mitigation options", it corresponds to some extent to what would be the conclusion of a research paper, and with expressions of the need for political action.

Here are two examples, showing that there are also obvious invitations to international cooperation, as in (3):

(3) Many options for reducing global GHG emissions through international cooperation exist. (IPCC 2007: 18)

... and that the push for action may be accompanied by some underlying equity thinking related to the differences of capacity for adaptation and mitigation in different countries or parts of the world, as in (4):

(4) Adaptive capacity is intimately connected to social and economic development

but is unevenly distributed across and within societies. (IPCC 2007: 14)

It is of course important to emphasise this equity or rights dimension in a document addressed to policymakers. I have noticed, however, that the IPCC document tries to keep the "promise" as stated in the description of their work, i.e., to be "policyrelevant and yet policy-neutral".

Now to the last section, 5, "The long-term perspective", contains a list of what is considered to be future key vulnerabilities, which then also constitute a description of future issues where more research is needed. This may be regarded as the "further research" component often included in the final part of a scientific paper. Interestingly, this last section starts with a promotion of the role of science in the climate change challenge, and thus with an underlying plea for more research:

(5) Determining what constitutes "dangerous anthropogenic interference with the climate system" in relation to Article 2 of the UNFCCC involves value judgements. Science can support informed decisions on this issue, including by providing criteria for judging which vulnerabilities might be labelled 'key'. (IPCC 2007: 18)

This overview of some macro aspects relevant for the genre perspective has shown that a text on scientific findings and assessments, made by scientists for policymakers, is not necessarily a genre with well-defined characteristics. The present document is a mix of a scientific paper and a political programme. In my presentation of more microlinguistic elements, we will see that some characteristics fit well with the scientific genre and some with the political one. But it should be kept in mind that this is just one observation arising from one investigation of many that should be undertaken on the rapidly developing climate discourse. And, in fact, it would be relevant to study this discourse from all the four methodological angles which have traditionally been adopted by GERAS: linguistic, didactic, cultural and technological. 


\subsection{Various "micro" perspectives related to polyphony}

\subsubsection{Introduction} here, i.e., the ScaPoLine theory (Nølke, Fløttum \& Norén 2004); ScaPoLine is short for " La théorie scandinave de polyphonie linguistique". However, what I can say - in a very simplistic way - is that this approach is based on a conception of language as fundamentally dialogic in nature (inspired by Ducrot 1984 and Bakhtine 1984), and presents itself as an alternative to the established idea of the uniqueness of the speaking subject. It helps to clarify complex multi-voiced sequences with both explicit and implicit positions, (selves and others, manifested explicitly in the presence of cited and named individuals or implicitly through various linguistic polyphonic markers, such as negation, adverbial phrases and connectives). For my further research, I would also like to make clear that I find it very fruitful to complement this mainly linguistic approach with the more discursive theory of dialogism, as developed by Jacques Bres, Sylvie Mellet, Alexandra Nowakowska, among others (see Bres et al. 2005; Bres \& Mellet 2009; Mellet 2009). Both approaches take as a point of departure the idea that discourse has the capacity of integrating voices which come in addition to the voice of the speaking subject, but there are differences in concepts and especially in scope. However, it seems clear that the two approaches could complement each other (Gjerstad forthcoming).

\subsubsection{Explicitly marked voices?}

31 I will start this part with the question to what extent the authors (forty all in all) are present, as a collective voice, since the summary represents the formally agreed statement of the IPCC. It is easy to make a first observation: there are in fact no occurrences of the first person plural pronoun WE. Even though there is always a sender behind each utterance, responsible for this utterance, there is not a single direct reference to the collective voice the forty authors represent. So the question, generally 
pertinent for both scientific and political discourse, about the role of personal (or indefinite) pronouns in a we/self versus they/other perspective (inclusion/exclusion) is not directly pertinent here. This absence of personal pronouns is an interesting finding in itself. However, their voices are of course present throughout the text; the person manifestation may be mapped by other devices. I will come back to this.

Regarding voice mixing, or the inclusion of other voices, this is typically done through bibliographical references in research papers. However, in this summary, which is probably expected not to contain this typical research characteristic, there are only a very few references to studies, and in most cases they seem to be part of the general basis of the summary and with no specific indications of which studies. Thus, when the IPCC says that "[d]iffering viewpoints existing within the scientific community are reflected" (see above), this is done in a non explicit way. There is one main voice - the one they have agreed to be the official IPCC voice. This leads us directly to the aspect of knowledge claims.

\subsubsection{Knowledge claims}

Given the structure I indicated above, there are a number of knowledge claims, especially in the "observed changes" or what I called the Result section, but also throughout the whole text. Generally, in research papers, knowledge claims typically appear first in the introduction section; thus there is correspondence in so far that the "observed changes" section is the first section of the summary.

We know that knowledge fields advance through the modification of existing and accepted research. There are at least three processes through which this takes place: a) new knowledge units are added to existing knowledge; b) existing units are altered, for example by complementing accepted research; c) existing 'facts' are replaced or rejected. These processes may represent different degrees of academic conflict (see Dahl 2008; Dahl \& Fløttum in press). There must of course have been many discussions and even conflicts during the work of the IPCC leading up to the 4th Assessment report. However, regarding the features we are looking at here, there are no explicit indications of such conflicts in the summary, even if the authors state that "[d]iffering viewpoints existing within the scientific community are reflected in the IPCC reports" (see above).

We will now take a closer look at how the knowledge claims are expressed. According to previous research (see for example Dahl 2008), their construction can be quite complex, in different ways. For example, they can be hedged or unhedged. Dahl (2008: 1184) points to the fact that claims [in her study on economics and linguistics] "may be signalled by expressions such as The key message is...". The reason for encouraging such explicit signalling of new claims, which should help to attract the attention of the research community, may be that the discipline in question is particularly competitive.

The purpose of our Summary is different. It is not to attract the attention of the research community but rather to attract the attention of the policymakers. The IPCC should present knowledge that is, as the authors themselves state, "policy-relevant and policy-neutral", with hopes and wishes for policymakers to proceed to action. In fact a large amount of the results reported do have an impersonal form such as "there is/are" followed by an expression related to research, observation, etc. (6) is an example, with the knowledge claim in the first sentence: 
(6) There is observational evidence of an increase in intense tropical cyclone activity in the North Atlantic since about 1970, with limited evidence of increases elsewhere. There is no clear trend in the annual numbers of tropical cyclones. It is difficult to ascertain longer-term trends in cyclone activity, particularly prior to 1970. (IPCC 2007: 2)

This knowledge claim is not marked in a specific way. The authors just refer to "observational evidence" for it. A further explanation of the claim is developed in the subsequent sentences: "no clear trend" of the numbers and difficulty "to ascertain longer-term trends". This passage is in fact highly illustrative of climate change knowledge and the forms used to express it: along with clear results come all the uncertainties due to insufficient numbers of investigations, continuous development of new models, and the long term perspective needed for ascertaining clear trends. This has to do with the specificity and the uniqueness of climate change. For policymakers the expressed uncertainties make it even more difficult to make the "right" decisions followed by concrete actions.

Since there are different degrees of uncertainties, the IPCC has established a systematic way of expressing them. The authors use what we in linguistics commonly would call epistemic modifiers such as likely and unlikely, superposing a voice of uncertainty on an underlying more categorical voice. These modifiers can in their turn be modified by different adverbial expressions such as very in very likely and more likely than not. Other similar combinations are medium, high or very high combined with agreement, evidence and confidence. What is special by these expressions is that they represent statistically calibrated expressions of uncertainty and confidence. In the text, they are all given in italics. See examples (7) to (9):

(7) It is very likely that over the past 50 years: cold days, cold nights and frosts have become less frequent over most land areas, and hot days and hot nights have become more frequent. It is likely that: heat waves have become more frequent over most land areas, the frequency of heavy precipitation events has increased over most areas, and since 1975 the incidence of extreme high sea level 3 has increased worldwide. (IPCC 2007: 2)

(8) There is high confidence that [...]. (IPCC 2007: 2)

(9) There is medium confidence that [...]. (IPCC 2007:3)

Since the issue stands between science and politics, it is essential that these scientific expressions are translated and understood correctly in the political context to which they are addressed. A claim like the one in (10) can be used and misused in different ways if the statistical understanding of "very likely" is not transferred:

(10) Most of the observed increase in global average temperatures since the mid-20th century is very likely due to the observed increase in anthropogenic GHG concentrations. (IPCC 2007: 5)

Summing up, we can say that in examples like these, there is one underlying rather categorical and unnuanced voice which is commented on by a well-defined scientific voice, signalled by the modifiers mentioned above. Problems and misunderstandings can occur both when the modifications are not taken into account and when they are taken into account, but incorrectly.

Before leaving the hedging expressions, I will briefly look into the use of some epistemic modifiers, also common in everyday language. I will not go into the comprehensive discussion of what should be regarded as a hedge, but just refer to the current and somewhat imprecise definition of hedging devices as expressions which are "toning down" or "mitigating" the propositional content of an utterance (see Lewin 
2005 for a thorough discussion; see also Hyland 1998 and Vold 2006). Central among these are modal verbs like may, might, could, and would. These words may of course convey quite different semantic content, but also the epistemic value of toning down the propositional content of the sentence in which it occurs. In the present context, this may be considered to be another example of polyphony, where the authors add their point of view as a comment to the unnuanced and underlying point of view, which can be their own, but perhaps at another stage of their work. Thus we have an internal discussion, with expressed uncertainty. Here is an example (my emphasis):

(11) Without substantial investment flows and effective technology transfer, it may be difficult to achieve emission reduction at a significant scale. Mobilising financing

of incremental costs of low-carbon technologies is important. (IPCC 2007: 20)

By the discussions both in scientific and political context taking place every day, we know now that it is difficult "to achieve emission reduction at a significant scale", not only that "it may be difficult". Prudent expressions like this one are related to the norm of being scientific, policy-relevant but also policy-neutral.

\subsubsection{Implicit voices involved through refutative and concessive polyphony}

We have already seen that there are no occurrences of personal pronouns referring directly to the voices corresponding to the responsible authors. We have also seen that the authors comment on underlying voices by both scientifically defined devices (the calibrated adverbials) and epistemic modifiers such as modal verbs. I will now turn to two specific devices which indicate mixed voices in constructions of refusal and concession, respectively.

I will limit my presentation mainly to a few examples of markers of this kind of implicit polyphony: i.e., the negation not (in its polemical use) and the contrastive connective but (in its concessive use). This limited selection is justified by the very frequent use of these specific markers in both political and scientific discourse in general, and in the current text in particular. I will show how the ScaPoLine theory (see above) may be applied, first by considering a simple example of negation, with refutative meaning:

(12) The long time scales of thermal expansion and ice sheet response to warming imply that stabilisation of GHG concentrations at or above present levels would not stabilise sea level for many centuries. (IPCC 2007: 20)

Formalised as follows:

Pov1: Stabilisation of GHG concentrations at or above present levels would stabilise sea level

Pov2: Pov1 is not valid

For practical reasons, I only consider the subordinated that-clause here. In this clause, two points of view (pov) are presented: one stating that "stabilisation of GHG concentrations at or above present levels would stabilise sea level" (pov1) and another qualifying this as not valid or false: "stabilisation of GHG concentrations at or above present levels would not stabilise sea level" (pov2). While the speaker (or locutor in ScaPoLine terms) is responsible for the latter point of view, the isolated utterance does not indicate who is the source of the first point of view. The source might or might not be identified through contextualisation. The speaker instance corresponds to the authors of the IPCC summary. The speaker's relation to the positive pov1 is one of nonresponsibility - more precisely, it is a refutative relation. In the interpretation of an utterance, it is important to determine the various points of view which are manifested, and to try to identify their sources, be it the speaker him- or herself, 
another person or group of persons, more or less defined, or some general opinion or doxa. Our knowledge of the context makes it reasonable to interpret the underlying and refuted point of view here as belonging to some climate sceptics.

Thus the interpretation process consists of several steps: identify the points of view, who is made responsible for each of them, to whom they are attributed and the relation between the speaker and the different points of view presented. The most important thing is to determine which point of view the speaker is responsible for.

I will now turn to an example of the polyphonic marker but in its contrastive and concessive capacity. In simple terms, a construction with but can be formalised as

(13) $\mathrm{p}$ but $\mathrm{q}$

where $\mathrm{p}$ and $\mathrm{q}$ constitute two propositions - or arguments - in contrast: $\mathrm{p}$ represents the concession and $q$ the argument that the speaker identifies him- or herself with. In the polyphonic analysis these are treated as points of view (pov). Example (14) constitutes an illustration of this construction:

(14) Such changes are projected to occur over millennial time scales, but more rapid sea level rise on century time scales cannot be excluded. (IPCC 2007:13)

In everyday language, the interpretation of (14) could be translated as follows: The speaker accepts that "such changes [referring to 'metres of sea level rise'] are projected to occur over millennial time scales". Implicitly this pov is also orienting the discourse towards a conclusion that there is "no reason to worry now". However, by the connective but, it is emphasised that what counts here and now is that "more rapid sea level rise on century time scales cannot be excluded", with an implicit conclusion saying "do worry!".

50 A pertinent question to ask in the interpretation process is who is responsible for the conceded pov. The utterance alone does not tell us. However, given the context of the IPCC work, this but-construction could be interpreted as an internal polyphonic exchange of points of view. There are different voices because of different research results but also because there is a lack of research. The first pov has as its source some results and the second other results. It is nevertheless important to note that what counts here and now for the speaking voice, is the proposition introduced by but.

51 I hope these few examples have shown that the polyphonic perspective may be relevant in this kind of discourse. In order to explore the complexity of both academic and political discourse, it is important to examine not only explicit but also implicit manifestations of voices involved. The polyphonic perspective provides a better picture of how these discourses actually work. It helps to detect subtle interactions contributing to the negotiation of different relations, represented by different voices.

To conclude this section, in any text there will be explicit and (more or less) implicit traces of different voices. What is not directly expressed in the text, but nevertheless indirectly present through various linguistic markers, is important for the interpretation of the text as a whole. The identification of such markers can also make the analyst sensitive to relevant contextual factors, and thus be a good starting point for a broader socio-political analysis of text. 


\section{Comparison of IPCC summary and ACCESS position paper}

53 I will now take a quick comparative look at the other document, mentioned in the introduction: "Position statement on climate change and related issues" written by ACCESS, the South-African Applied Center for Climate and Earth Systems Science (ACCESS). The situation in which this document was produced is very different from the situation of the IPCC document.

The ACCESS document was produced for a public hearing on climate change issues organised by the Parliament of the Republic of South Africa, 17-18 November 2009. ACCESS is an applied center, which is already different from the "hard core research" on which IPCC assessments are based. In addition, taking part in a public hearing implies - at least normally - an action-oriented or political message. As a first point of comparison, I have noted that the overarching structure, as indicated by the subtitles, is much less "research-paper-like" than the IPCC text.

55 I have not done any statistical calculations of the significance of quantitative differences, because of the small amount of data, but there are some interesting tendencies to note. The most important are set up in table 1.

Table 1. Comparison between IPCC and ACCESS

\begin{tabular}{|l|l|l|}
\hline Document/Features & IPCC & ACCESS \\
\hline Words number & 5,550 & 3,200 \\
\hline Explicitly marked voices & - & 29 we \\
\hline Knowledge claims & impersonal & + - impersonal \\
\hline Hedging & $\begin{array}{l}\text { Statistically calibrated } \\
\text { modifiers/adverbs }\end{array}$ & - \\
\hline Hedging & $\begin{array}{l}\text { Modal verbs: } \\
\text { may (10), would (16), } \\
\text { could (11) }\end{array}$ & $\begin{array}{l}\text { may (1), would (2), } \\
\text { could (3) }\end{array}$ \\
\hline Implicit voices by not & 13 (rel. freq.: 0.23\%) & 14 (rel. freq.: 0.44\%) \\
\hline Implicit voices by but & 13 (rel. freq.: 0.23\%) & 13 (rel. freq.: 0.41\%) \\
\hline
\end{tabular}

First, The IPCC document (excl. figures and tables) contains about 5,500 words, while the ACCESS document contains about 3,200 (hereafter IPCC and ACCESS). One of the two most obvious differences is related to the factor of explicitly marked voices. While there are no personal pronouns referring directly to the authors in IPCC, there are 29 occurrences of we in ACCESS.

57 As previously seen, knowledge claims in IPCC are impersonally introduced, typically by there is/are. We find the same type in ACCESS, even though quite rare. But in ACCESS we 
also find personally-coloured claims, by different adverbial expressions, as in "Clearly, there is an urgent need to reduce the uncertainties inherent in all of these considerations."

The second most obvious difference is related to hedging: IPCC uses the statisticallycalibrated modifiers (such as likely, with high confidence), a clear marker of scientific presentation. ACCESS does not contain such markers. In fact, hedging by modal verbs is also much less frequent in ACCESS than in IPCC (see table 1 for the figures). Finally, when it comes to implicit voices involved, signalled by the markers not and but, we see that ACCESS has a higher relative frequency than IPCC, i.e., there is more concessive and refutative polyphony in ACCESS. Here are some examples:

(15) Climate change is clearly a global challenge but its causes and impacts are not evenly distributed [...].

(16) Furthermore, we do not adequately understand the processes that mediated the historical changes to the earth's climate in the planets geological past.

(17) The role of science is not only to assess change and the impact of change, but to produce the technical skills to address these dilemmas.

From these examples we can conclude that ACCESS is more polemical and polyphonic than IPCC, a characteristic that places this document more clearly on the political than on the scientific genre side. In addition, explicitly marked voices by the pronoun we are much more frequent. For the use of we, it has to be pointed out that the reference of this pronoun is very often not clear and can represent an interpretative challenge (in this document, the pronoun can refer to the authors, to scientists, scientists and politicians, South African (SA) scientists, SA politicians, SA people, Africans in general, the developing world, the whole world).

Further, we can be exclusive (we versus you/they) or inclusive, with different referential scopes. Finally, the we-inclusion may also be felt as imposing or patronising. Here are some examples, taken from passages which also show that the ACCESS text is more engaged and action-oriented than the IPCC text:

(18) Thus we need to understand that our Southern African domain extends well beyond the African landmass, [...].

(19) In order to solve these dilemmas, we need to find a way to provide meaningful and urgent development [...].

(20) We are thus led to ask the question: How are the impacts of climate change distinguished from the impacts of poverty and under-development? [...] What are our most urgent needs [...]?

61 I would now like to move on to my final remarks, a summing up with some considerations related to the genre perspective.

\section{Final remarks and summing up on "climate change narratives"}

First I would like to bring up the questions related to what the IPCC authors say about themselves. They want to be clear; whether they are sufficiently clear can of course be discussed along different perspectives. However, they use a scientifically-based system of calibrated expressions, epistemic modifiers, which are clearly defined. They also say that "[d]iffering viewpoints existing within the scientific community" are reflected. I have pointed out that the text is to some extent polyphonic, but differing viewpoints or 
voices are not identified. They present a common voice and are often discussing with themselves. Some implicit critical voices are brought in, but not identified.

Then, to what extent is the summary "policy-relevant and yet policy-neutral, never policy-prescriptive"? This could be discussed more thoroughly than I can do here. However, in my opinion, the examples presented and the features studied show that the IPCC summary is both policy-neutral by the results of scientific investigations, and policy-relevant, at least for those of us who believe that global warming is a fact. They are not explicitly policy-prescriptive, but implicitly and by different polyphonic structures they urge to some specific political actions.

Without returning to the details of the ACCESS document, the comparison that I have just presented indicates that the IPCC is more scientific than the ACCESS document, which is more political, and more action-oriented. This is of course due to the situational context in which they were produced, but also to the institutional difference between them. However, there is a mix of science and politics in both. And they are both polyphonic, but to different degrees and in different ways.

These considerations, together with preliminary studies of different documents related to climate change in the larger project the present analysis is part of, lead me to the following conclusion: There is obviously not one discursive genre in which we can put all these documents. Rather, they are part of climate change narratives ( $\mathrm{CCN})$. By climate change narratives I understand verbal constructions or stories that present climate change as a certain type of problem, with implicit or explicit suggestions for action. They may be based on knowledge from the natural or social sciences, and influenced by political and ideological points of view; thus, hybrids of scientific and political voices.

Using narrative as a common denominator for the material to be studied must of course not be taken too literally. I do not claim that the narratives we are discussing are identical to classical narratives such as fairy tales (in the fictional world) or newspaper stories ("faits divers", in the non-fictional world). However, there are certain crucial points that may be regarded as common or at least similar. The most important is the overarching characteristic of narratives as having a plot (or an intrigue), i.e., they recount a sequence of events or actions which take place to achieve some particular effect(s), through specific components making up a textual structure.

The structure of the narrative sequence has been discussed since ancient times, but different approaches tend to agree that there are five components (see for example Adam 1999):

8 1) initial situation (or orientation), 2) complication (an event or action which creates difficulties; "déclencheur" - release mechanism), 3) re-action(s), 4) re-solution (act of resolving, "dénouement") and 5) final situation. A narrative may also include a final moral evaluation.

Further, it is commonly accepted that in order to be characterised as a narrative, all the five components are not obligatory. The core is constituted by the three middle factors, and among them, the "complication" is mandatory. For climate change narratives, we think it is legitimate to claim that the complication factor is climate change itself. Regarding components 3 and 4, our hypothesis is that they can be realised at different degrees according to the situations and actors involved. Component 1 may be present in different ways, and component 5 may be realised in descriptions of how our world will evolve if we undertake such and such action. There may also be an evaluation 
component, in fact the evaluation is often present in climate narratives produced by activist groups or by politicians.

To sum up, by climate change narratives I understand constructions or stories that present climate change as a certain type of problem ('complication'), with implicit or explicit suggestions for action, and with a more or less clear evaluation component.

Regarding the two texts analysed here, it seems reasonable to interpret the IPCC text as allowing the complication component to dominate while the ACCESS text also contains clear passages which fit into the action component, accompanied by different evaluative components.

This is a claim that has to be discussed, of course. Whatever the conclusion, what is certain is that we do not have sufficient understanding of the relations between scientific knowledge and political action. The uniqueness and the complexity of climate change do challenge political action and processes, but also shape narratives. In order to understand these narratives, linguists and discourse experts have a lot of work to do!

\section{BIBLIOGRAPHY}

\section{Primary sources}

ACCESS. 2009. "Position statement on climate change and related issues". Accessed in March 2010. <http://www.africaclimatescience.org/news.php?p=52>.

IPCC. 2007. "Synthesis Report Summary for Policymakers"; IPCC Fourth Assessment Report: Climate Change 2007. Accessed in March 2010. <http://www.ipcc.ch/publications_and_data/ar4/ syr/en/spm.html>.

Environmental Law and Climate Change Law Blog. Accessed Feb 5th, $2010<\mathrm{http}: / /$ taberlaw.wordpress.com/>.

References

Adam, Jean-Michel. 1999. Linguistique textuelle. Des genres de discours aux textes. Paris: Nathan.

Bakhtine, Mikhaïl. 1984 [1952]. "Les genres du discours". In Esthétique de la création verbale. Paris: Gallimard, 265-308.

Bres, Jacques and Sylvie Mellet. 2009. "Une approche dialogique des faits grammaticaux". Langue française 163, 3-20.

Bres, Jacques, Pierre-Patrick Haillet, Sylvie Mellet, Henning Nølke and Laurence Rosier (eds.). 2005. Dialogisme, polyphonie : approches linguistiques. Bruxelles: De Boeck-Duculot.

Charaudeau, Patrick. 2005. Le discours politique. Les masques du pouvoir. Paris: Vuibert.

Chilton, Paul and Christina Schäffner. 2002. Politics as Text and Talk. Analytic approaches to political discourse. Amsterdam/Philadelphia: John Benjamins Publishing Company.

Dahl, Trine. 2008. "Contributing to the academic conversation: A study of new knowledge claims in economics and linguistics". Journal of Pragmatics 40/7, 1184-1201. 
Dahl, Trine and Kjersti Fløttum. (in press). "Wrong or just different? How existing knowledge is staged to promote new claims in economics and linguistics". In Salager-Meyer F. \& B. Lewin (eds.), The Word and the Sword: Criticism in the Academy. Bern: Peter Lang.

Ducrot, Oswald. 1984. Le Dire et le Dit. Paris: Minuit.

Fløttum, Kjersti. 2005a. "MOI et AUTRUI dans le discours scientifique : l'exemple de la négation NE...PAS”. In Bres, J., P.-P. Haillet, S. Mellet, H. Nølke \& L. Rosier (eds.), Dialogisme, polyphonie: approches linguistiques. Bruxelles: De Boeck-Duculot, 323-337.

Fløttum, Kjersti. 2005b. "The self and the others - polyphonic visibility in research articles". International Journal of Applied Linguistics 15/1, 29-44.

Fløttum, Kjersti. 2006. “Interrelation de voix internes et externes dans le discours". In Perrin, L. (ed.), Le sens et ses voix. Metz: Recherches Linguistiques 28, 301-322.

Fløttum, Kjersti. 2010. "EU discourse: polyphony and unclearness”. Journal of Pragmatics 42/4, 990-999.

Fløttum, Kjersti and Trine Dahl. (forthcoming 2011). "Climate change discourse: scientific claims in a policy setting". Fachsprache.

Fløttum, Kjersti, Trine Dahl and Torodd Kinn. 2006. Academic Voices - across languages and disciplines. Amsterdam/Philadelphia: John Benjamins Publishing Company.

Fløttum, Kjersti and Øyvind Gjerstad. (forthcoming). "Mélange de voix dans le discours politique de l'Union européenne”. In Kara M., L. Perrin and A. Petitjean (eds.), Polyphonie - Perspectives théoriques et didactiques. Metz, France: CELTED, Université Paul Verlaine.

Fløttum, Kjersti and Dag Stenvoll. 2009. "Blair speeches in a polyphonic perspective. NOTs and BUTs in visions on Europe". Journal of Language and Politics 8/2, 269-286.

Gjerstad, Øyvind. 2007. “The Polyphony of politics: Finding voices in French political discourse. Critical Approaches to Discourse Analysis Across Disciplines 1/2, 61-78.

Gjerstad, Øyvind. (forthcoming). La polyphonie linguistique et le dialogisme pragmatique dans l'analyse du discours.

Hyland, Ken. 1998. Hedging in Scientific Research Articles. Amsterdam/Philadelphia: John Benjamins Publishing Company.

Hyland, Ken. 2000. Disciplinary discourses: Social interactions in academic writing. Harlow: Longman.

Lewin, Beverly A. 2005. "Hedging: an exploratory study of authors' and readers' identification of 'toning down' in scientific texts". Journal of English for Academic Purposes 4/2, 163-178. <http:// www.sciencedirect.com/science/journal/14751585>.

Malone, Elizabeth. 2009. Debating Climate Change. Pathways through argument to agreement. London: EarthScan.

Mayaffre, Damon. 2007. "Vocabulaire et discours électoral de Sarkozy : entre modernité et pétainisme". La Pensée 352, 65-80.

Mellet, Sylvie. 2009. "Dialogisme, parcours et altérité notionnelle : pour une intégration en langue du dialogisme ?”. Langue française 163, 157-173

Mellet, Sylvie and Dominique Longrée. 2009. "New Approaches in Text Linguistics”. Belgian Journal of Linguistics 23. Amsterdam/Philadelphia: John Benjamins Publishing Company. 
Nølke, Henning, Kjersti Fløttum and Coco Norén. 2004. ScaPoLine. La théorie scandinave de la polyphonie linguistique. Paris: Kimé.

Poudat, Céline and Damon Mayaffre. 2009. "Issues and methods of political logometry: An application to the French presidential discourse". Paper given at seminar at Maison des Sciences de l'Homme, Paris, 30 January 2009.

Prelli, Lawrence J. 1989. A Rhetoric of Science: Inventing Scientific Discourse. Columbia: University of South Carolina Press.

Rastier, François 1998. "Le problème épistémologique du contexte et le statut de l'interprétation dans les sciences du langage”. Langages 129, 97-111.

Rinck, Fanny, François Boch and Francis Grossmann. 2007. "Quelques lieux de variation du positionnement énonciatif dans l'article de recherche”. In Lambert, P., A. Millet, M. Rispail \& C. Trimaille (eds.), Variations au cœur et aux marges de la sociolinguistique. Paris: L'Harmattan, 285-296. Rouveyrol, Laurent. 2009. "Towards an integrative logometry of political discourse: Obama in the limelight". Paper given at seminar at Maison des Sciences de l'Homme, Paris, 30 January 2009.

Rowley-Jolivet, Elizabeth and Shirley Carter-Thomas. 2008. "When practice belies 'theory': Form, function and frequency of if-conditionals in specialised discourse". ASp 53-54, 39-61.

St. Clair, Asuncion L. 2006. "Global Poverty: The Co-Production of Knowledge and Politics". Journal of Global Social Policy 6/1, 57-77.

Swales, John M. 1990. Genre Analysis. English in Academic and Research Settings. Cambridge: Cambridge University Press.

van Dijk, Teun A. 1997. “The Study of Discourse”. In van Dijk, T. A. (ed.), Discourse as Social Interaction: Discourse Studies vol 2. - A Multi-Disciplinary Introduction. London: Sage, 1-38.

Weiss, Gilbert, 2002. "Searching for Europe: The problem of legitimisation and representation in recent political speeches on Europe". Journal of Language and Politics 1, 59-83.

Wodak, Ruth and Paul Chilton (eds). 2005. A New Agenda in (Critical) Discourse Analysis: Theory, Methodology and Interdisciplinarity. Amsterdam/Philadelphia: John Benjamins Publishing Company.

Wodak, Ruth and Gilbert Weiss. 2004. "Visions, Ideologies and Utopias in the Discursive Construction of European Identities". In Pütz, M., J. Neff-van Aertselaer and T. A. van Dijk (eds.), Communicating Ideologies: Multidisciplinary Perspectives on Language, Discourse, and Social Practice. Bern: Peter Lang.

\section{NOTES}

1. Article author's italics 


\section{ABSTRACTS}

As climate change debate is rapidly evolving, we hear a multitude of voices: different actors are getting involved around addressing the challenges, setting priorities for new knowledge, and framing key questions and actions. Whose voices are these? And how are they "translating" each other's knowledge? In order to answer these questions, it is necessary to study how climate knowledge, which has its origin in "objective" scientific discourse, is transmitted to public and political argumentative or action-oriented discourse. How do actors at different levels construct their climate politics linguistically? The interdisciplinary research project to which this paper is related aims to unpack this polyphonic discourse. In the present contribution, an analysis of a document produced by the Inter-governmental Panel on Climate Change (IPCC) is undertaken: the "Summary for policymakers" with the main IPCC findings from 2007. This document takes climate research findings as a point of departure and puts an emphasis on the need of adaptation and political action.

Dans les débats sur le changement climatique, une multitude de voix se font entendre : différents acteurs s'attellent aux défis, définissent les priorités pour de nouvelles connaissances et fournissent un cadre pour les questions et actions clés. À qui appartiennent ces voix ? Comment traduisent-elles leurs connaissances respectives? Afin de répondre à ces questions, il est nécessaire d'étudier comment le changement climatique, qui a son origine dans un discours scientifique "objectif», est transposé en un discours argumentatif et orienté vers l'action. Comment les acteurs construisent-ils linguistiquement leur agenda climatique? Le projet interdisciplinaire auquel cet article est lié a pour but de dévoiler ce discours polyphonique. Dans la présente contribution sera entreprise une analyse portant sur un document produit par le Intergovernmental Panel on Climate Change (IPCC), « Summary for policymakers », contenant les résultats principaux de l'IPCC de 2007. Ce document prend les résultats scientifiques comme point de départ et porte une attention particulière à la nécessité de l'adaptation et de l'action politique.

\section{INDEX}

Mots-clés: analyse du discours, climat, narration, politique, polyphonie, science

Keywords: climate, discourse analysis, narrative, politics, polyphony, science

\section{AUTHOR}

\section{KJERSTI FLØTTUM}

Kjersti Fløttum is Professor of French linguistics at the Department of Foreign Languages, and Head of Bergen Summer Research School <www.bsrs.no>, University of Bergen, Norway $<$ www.uib.no>. Her general research fields are text linguistics, discourse analysis, semantics and pragmatics. More specifically her research and publications are related to linguistic polyphony and genre theory, with empirical support from scientific and political discourse.

kjersti.flottum@if.uib.no 